\title{
Cytotoxic Compounds from Kibatalia gitingensis (Elm.) Woodson
}

\author{
Mariquit M. De Los Reyes ${ }^{1,2}$, Glenn G. Oyong ${ }^{3}$, Vincent Antonio S. $\mathrm{Ng}^{4}$, Chien-Chang Shen ${ }^{5}$, \\ Consolacion Y. Ragasa ${ }^{4,6}$
}

Mariquit M. De Los Reyes ${ }^{1,2}$, Glenn G. Oyong ${ }^{3}$, Vincent Antonio S. $\mathrm{Ng}^{4}$, Chien-Chang Shen ${ }^{5}$ Consolacion Y. Ragasa ${ }^{4,6}$

'Biology Department, De La Salle University Science \& Technology Complex, Leandro V. Locsin Campus, Biñan City, Laguna 4024, PHILIPPINES. 2Biology Department, De La Salle University, 2401 Taft Avenue, Manila 0922, PHILIPPINES. ${ }^{3}$ Center for Natural Science and Environmental Research, De La Salle University, 2401 Taft

Avenue, Manila 0922, PHILIPPINES.

${ }^{4}$ Chemistry Department, De La Salle University, 2401 Taft Avenue, Manila 0922, PHILIPPINES.

${ }^{5}$ National Research Institute of Chinese Medicine, Ministry of Health and Welfare, 155-1, Li-Nong St., Sec. 2, Taipei 112, TAIWAN. ${ }^{6}$ Chemistry Department, De La Salle University Science \& Technology Complex, Leandro V. Locsin Campus, Biñan City, Laguna 4024, PHILIPPINES.

\section{Correspondence}

Mariquit M. De Los Reyes, Ph.D, Biology Department, De La Salle University Science \& Technology Complex, Leandro V. Locsin Campus, Biñan City, Laguna 4024, PHILIPPINES. Telephone: + 63495548900 Local $112 ;+632536-0228$

E-mail: mariquit.delosreyes@dlsu.edu.ph History

- Submission Date: 08-07-2016;

- Review completed: 22-07-2016;

- Accepted Date: 10-08-2016.

DOI : 10.5530/pj.2017.1.2

Article Available online

http://www.phcogj.com/v9/i1

\section{Copyright}

(C) 2016 Phcog.Net. This is an openaccess article distributed under the terms of the Creative Commons Attribution 4.0 International license.

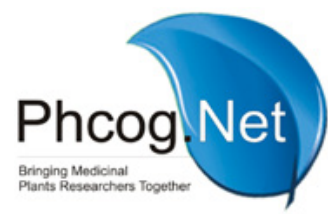

\section{ABSTRACT}

Ursolic acid (1), squalene (2), a mixture of $\alpha$-amyrin acetate (3a) and lupeol acetate (3b), and isoscopoletin (4), isolated from the dichloromethane extracts of the leaves and twigs of Kibatalia gitingensis, were evaluated for their cytotoxic activities against three human cancer cell lines, breast (MCF-7) and colon (HT-29 and HCT-116), and a normal cell line, human dermal fibroblast-neonatal (HDFn), using the in vitro PrestoBlue ${ }^{\circledR}$ cell viability assay. Compounds 1-4 exhibited strong cytotoxic activities against HT-29 cells with $\mathrm{IC}_{50}$ values ranging from 0.6931 to $1.083 \mu \mathrm{g} / \mathrm{mL}$. Furthermore, $1-4$ were moderately cytotoxic against HCT-116 cells with $I_{50}$ values ranging from 4.065 to $11.09 \mu \mathrm{g} / \mathrm{mL}$. These compounds were least cytotoxic against MCF-7 cells with $\mathrm{IC}_{50}$ values ranging from 8.642 to $25.87 \mu \mathrm{g} / \mathrm{mL}$. The most cytotoxic against HT-29 cells, HCT-116 cells and MCF-7 cells are 2, 4 and 1, respectively.

Key words: Kibatalia gitingensis, Apocynaceae, Ursolic acid, Squalene, $\alpha$-amyrin acetate, Lupeol acetate, Isoscopoletin, Cytotoxicity, MCF-7, HCT-116, HT-29, HDFn, PrestoBlue ${ }^{\circledR}$ cell viability assay.

\section{INTRODUCTION}

Kibatalia gitingensis (Elm.) Woodson, of the family Apocynaceae, is native to the Philippines where it is locally known as "laniti" or "laneteng-gubat". It is classified as vulnerable in the IUCN Red List of Threatened Species. ${ }^{1}$ It is commonly used to make building materials and decorative carvings and is also known to contain medicinal properties due to its alkaloid content. ${ }^{2}$ The leaves of $K$. gitingensis yielded a steroidal alkaloid, gitingensine, which was found to exhibit antispasmodic activity ${ }^{3,4}$ and ataraxic properties, able to tranquilize smooth muscles as well as vasodilate arteries of the skeletal muscles and the splanchnic region. ${ }^{5}$ Other studies reported that the leaves of $K$. gitingensis contain kibataline ${ }^{6,7}$ and 20-(epi- $N$-methyl) paravallarine. ${ }^{8}$ The plant contains an azasteroidal alkaloid which caused spontaneous motility in mouse and dog intestines and likewise removed serotonin-induced contractions. ${ }^{9}$ The bark of K. gitingensis yielded a complex mixture of alkaloids, including paravallarine, $\mathrm{N}$-methylparavallarine, and 20 -epiparavallarine. ${ }^{10}$ Moreover, the stem bark of the plant was reported to contain lanitine ( $2 \alpha$-hydroxy$N$-methylparavallarine) and its $2 \beta$-isomer. ${ }^{11}$

This study is part of our research on the chemical constituents and bioactivities of plants endemic and native to the Philippines. We recently reported the isolation and identification of ursolic acid (1), squalene (2), a mixture of $a$-amyrin acetate (3a) and lupeol acetate (3b) from the leaves, and 1-3 and isoscopoletin
(4) from the twigs, of K. gitingensis (Figure 1). ${ }^{12} \mathrm{We}$ report herein the results of the cytotoxicity studies on 1-4 from the leaves and twigs of $K$. gitingensis.

\section{MATERIALS AND METHODS}

\section{Sample Collection}

Samples of leaves and twigs of Kibatalia gitingensis (Elm.) Woodson were collected from the De La Salle University-Science and Technology Complex (DLSU-STC) reforested area in February 2014. The samples were authenticated and deposited at the De La Salle University Herbarium with voucher specimen \#908.

\section{Isolation and Structure Elucidation}

The isolation and structure elucidation of 1-4 from the leaves and twigs of $K$. gitingensis were reported previously. ${ }^{12}$

\section{Preparation of Compounds for Cytotoxicity Tests}

The compounds (1-4) from K. gitingensis were dissolved in dimethyl sulfoxide (DMSO) to make a $4 \mathrm{mg} / \mathrm{mL}$ stock solution. Working solutions were prepared in complete growth medium to a final non-toxic DMSO concentration of $0.1 \%$. 

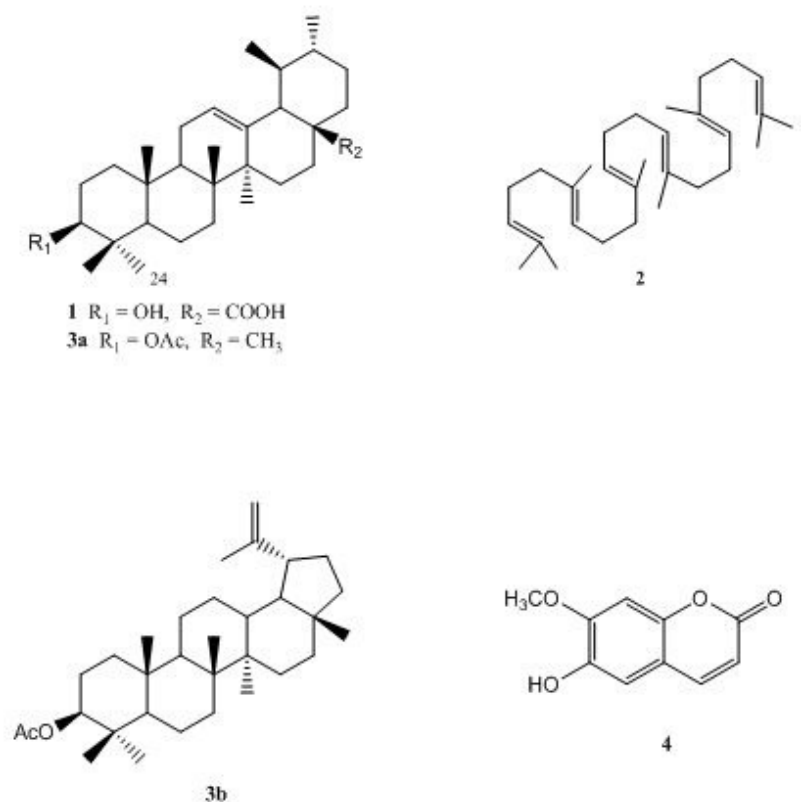

Figure 1: Chemical structures of ursolic acid (1), squalene (2), a-amyrin acetate (3a), lupeol acetate (3b), and isoscopoletin (4) from Kibatalia gitingensis.

\section{Maintenance and Preparation of Cells for Cytotoxicity Tests}

The cytotoxicity of $\mathbf{1 - 4}$ from the dichloromethane $\left(\mathrm{CH}_{2} \mathrm{Cl}_{2}\right)$ extracts of $K$. gitingensis was tested on the following human cell lines: breast cancer (MCF-7) and colon cancer (HCT-116 and HT-29) (ATCC, Manassas, Virginia, U.S.A.), and human dermal fibroblast-neonatal (HDFn; Invitrogen Life Technologies, U.S.A.), which are routinely maintained at the Cell and Tissue Culture Laboratory, Molecular Science Unit, Center for Natural Science and Environmental Research, De La Salle University, Manila, Philippines. Following standard procedures, ${ }^{13,14}$ cells were grown in Dulbecco's Modified Eagle Medium (DMEM, Gibco ${ }^{\circ}$ USA) containing $10 \%$ fetal bovine serum (FBS, Gibco ${ }^{\circ}$, USA) and $1 \mathrm{x}$ antibiotic-antimycotic (Gibco ${ }^{\circ}$, USA) and kept in an incubator $\left(37^{\circ} \mathrm{C}, 5 \% \mathrm{CO}_{2}\right.$, $98 \%$ humidity). At $80 \%$ confluence, the monolayers were washed with phosphate-buffered saline (PBS, pH 7.4, Gibco ${ }^{\circledR}$, USA), trypsinized with $0.05 \%$ Trypsin-EDTA (Gibco ${ }^{\circ}$, USA), and resuspended with fresh complete media. Cells were counted following standard trypan blue exclusion method using $0.4 \%$ Trypan Blue Solution (Gibco ${ }^{\circ}$, USA). Cells were seeded in $100-\mu \mathrm{L}$ aliquots into a 96 -well microtiter plate $\left(\mathrm{Falcon}^{\mathrm{TM}}\right.$, USA) using a final inoculation density of $1 \times 10^{4}$ cells/well. The plates were further incubated overnight $\left(37^{\circ} \mathrm{C}, 5 \% \mathrm{CO}_{2}, 98 \%\right.$ humidity) until complete cell attachment was reached. These cells were used for the cytotoxicity studies as described below.

\section{Cell Viability Assay}

The cytotoxicity of the K. gitingensis compounds was determined in an in vitro cell viability assay using PrestoBlue ${ }^{\circledast}$ (Molecular Probes ${ }^{\oplus}$, Invitrogen, USA). This test is based on the principle that the enzyme, mitochondrial reductase, present in viable cells, can reduce the nonfluorescent, blue resazurin dye in the reagent, converting it to resorufin which is red and highly fluorescent. Hence, only viable cells are able to cause color change. The conversion is proportional to the number of metabolically active cells and is correlated to absorbance measurements. To the monolayers in the microtiter plate, $100 \mu \mathrm{L}$ of filter-sterilized 1-4 were added to corresponding wells at two-fold serial dilutions to make final screening concentrations of $50,25,12.5,6.25,3.12,1.56,0.78$, and
$0.39 \mu \mathrm{g} / \mathrm{mL}$. Wells with no compound served as negative controls, wells with $\mathrm{Zeocin}^{\mathrm{TM}}$ (Gibco ${ }^{\oplus}$, USA) served as positive controls, and wells containing only cell culture media were used to correct for background color. The cells were further incubated $\left(37^{\circ} \mathrm{C}, 5 \% \mathrm{CO}_{2}, 98 \%\right.$ humidity) for 4 days. Ten microliters of PrestoBlue ${ }^{\infty}$ was added to each well. The cells were incubated $\left(37^{\circ} \mathrm{C}, 5 \% \mathrm{CO}_{2}, 98 \%\right.$ humidity) for $2 \mathrm{hr}$. Absorbance measurements were carried out using the BioTek ELx800 Absorbance Microplate Reader (BioTek ${ }^{\circledast}$ Instruments, Inc., U.S.A.) at $570 \mathrm{~nm}$ and normalized to $600 \mathrm{~nm}$ values (reference wavelength). Absorbance readings were used to calculate for the cell viability for each sample concentration following the equation below.

$$
\begin{gathered}
\text { Cell viability }(\%)=\frac{\begin{array}{l}
\text { Absorbance of Treated sample }- \\
(\text { Absorbance of Blank })
\end{array}}{\text { Absorbance of Blank })} \times 100
\end{gathered}
$$

Nonlinear regression and statistical analyses were done using GraphPad Prism 7.00 (GraphPad Software, Inc.) to extrapolate the half maximal inhibitory concentration, $\mathrm{IC}_{50}$, the concentration of the compound which resulted in a $50 \%$ reduction in cell viability. The cytotoxicity of 1-4 was expressed as $\mathrm{IC}_{50}$ values. All tests were performed in triplicates and data were shown as means. The extra sum-of-squares $\mathrm{F}$ test was used to evaluate the differences in the best-fit parameter (half maximal inhibitory concentration) among data sets (treatments) and to determine the differences among dose-response curve fits according to the software's recommended approach. One-way ANOVA $(\mathrm{p}<0.05)$ was also used to determine significant differences among treatments, followed by Tukey's multiple comparison post hoc test $(\mathrm{p}<0.05)$, to compare different pairs of data sets. Results were considered significant at $\mathrm{p}<0.05$.

\section{RESULTS AND DISCUSION}

Ursolic acid (1), squalene (2), a mixture of $\alpha$-amyrin acetate (3a) and lupeol acetate (3b), and isoscopoletin (4), isolated from the dichloromethane extracts of the leaves and twigs of $K$. gitingensis, were evaluated for their anti-proliferative activities against three human cancer cell lines, breast (MCF-7) and colon (HT-29 and HCT-116), and a normal cell line, human dermal fibroblast-neonatal (HDFn), using the in vitro PrestoBlue ${ }^{\varpi}$ cell viability assay.

The $\%$ cell viability as a function of the logarithmic values of compound concentration is shown in Figures 2 and 3. Most plots nearly follow the typical sigmoidal curve which is characteristic of an inhibitory doseresponse relationship between treatments and cell viability. Figure 2 compares the anti-proliferative effects per cell line, while Figure 3 compares the effects per compound. The corresponding $\mathrm{IC}_{50}$ values are summarized in Table 1.

The breast cancer cell line (MCF-7) is only moderately susceptible to $\mathbf{1}$ and $\mathbf{3 a}$ and $\mathbf{3 b}$, with $\mathrm{IC}_{50}$ values of 8.642 and $11.13 \mu \mathrm{g} / \mathrm{mL}$, respectively, and least susceptible to 2 and 4 with $\mathrm{IC}_{50}$ values of 25.87 and $23.35 \mu \mathrm{g} / \mathrm{mL}$. One-way ANOVA showed statistical difference between treatments $(\mathrm{p}<0.0001)$, but Tukey's multiple comparison post hoc test revealed that there are no pairwise differences between $\mathbf{1}$ and $\mathbf{3 a}$ and $\mathbf{3 b}$, and $\mathbf{2}$ and $\mathbf{4}$ ( $\mathrm{p}>0.05)$.

The colon cancer cell line (HCT-116) is most susceptible to 4 with $\mathrm{IC}_{50}$ values of $4.065 \mu \mathrm{g} / \mathrm{mL}$, but showed moderate susceptibility only to 1,2 , and $\mathbf{3 a}$ and $\mathbf{3 b}$, with $\mathrm{IC}_{50}$ values of 7.225, 9.226, and $11.09 \mu \mathrm{g} / \mathrm{mL}$, respectively. One-way ANOVA showed that all treatments are statistically different $(p<0.0001)$, but Tukey's multiple comparison post hoc test showed no pairwise differences between $\mathbf{1}$ and $\mathbf{2}$, and $\mathbf{2}$ and $\mathbf{3 a}$ and $\mathbf{3 b}$ ( $p>0.05)$. The growth of the other colon cancer cell line (HT-29) exhibited 

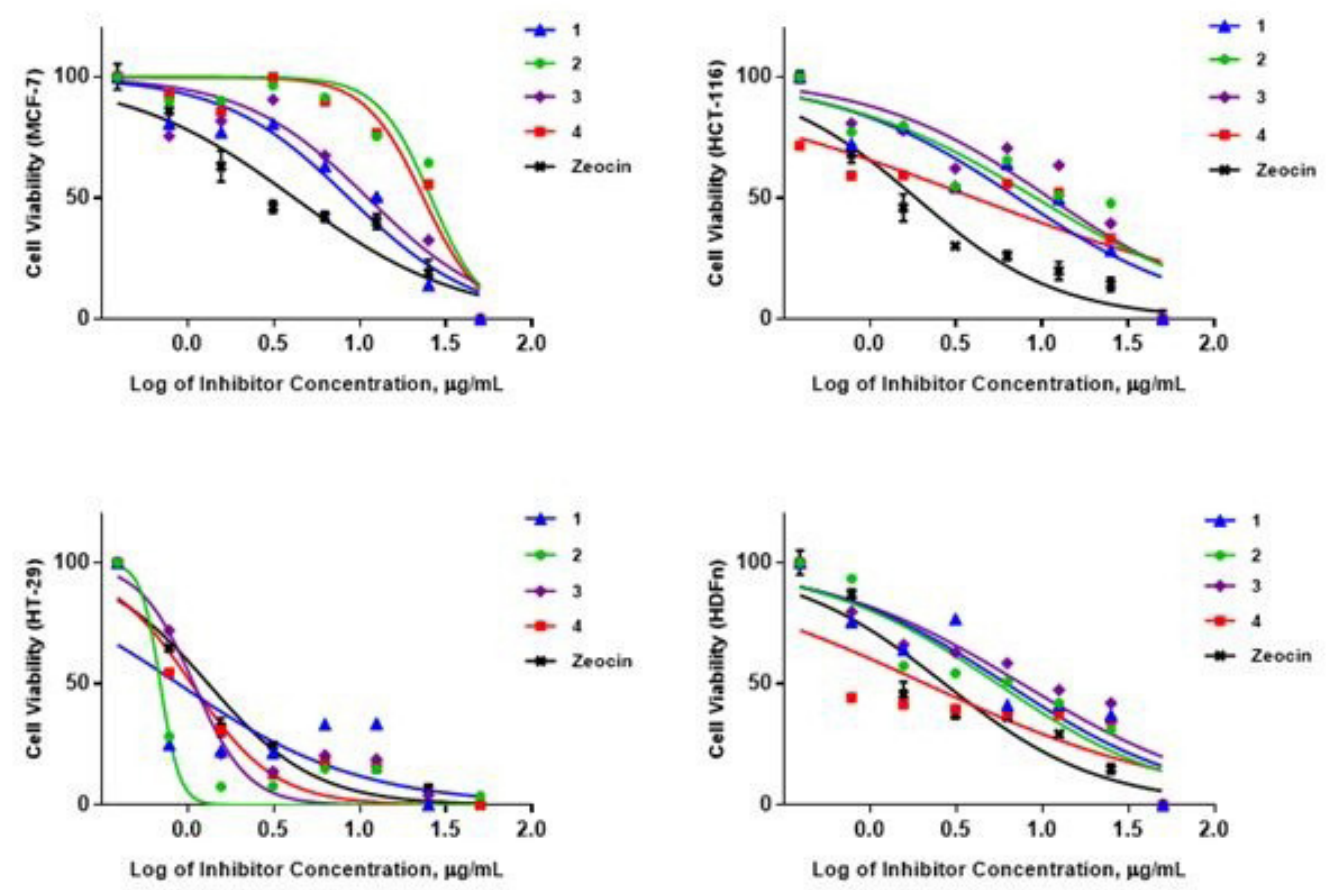

Figure 2: Cytotoxic activities of 1-4 and Zeocin (per cell line). Extra sum-of-squares $\mathrm{F}$ test was performed to evaluate differences in: (A) best-fit parameters $\left(\mathrm{IC}_{50}\right)$ among treatments, (B) dose-response curve fits. Results: MCF-7 (A) F(DFn, DFd) $=F(5,124)=4.398, p=0.0010$ and $(B) F(10,124)=8.142$, $p<0.0001 ; H C T-116$ (A) $F(5,123)=4.477, p=0.0009$ and $(B) F(10,123)=2.513, p=0.0087 ; H T-29(A) F(5,124)=3.419, p=0.0063$ and (B) $F(10,124)=2.221, p=0.0205 ; H D F n(A) F(5,124)=2.62$, $\mathrm{p}=0.0274$ and $(\mathrm{B}) \mathrm{F}(10,124)=1.888, \mathrm{p}=0.0528$.

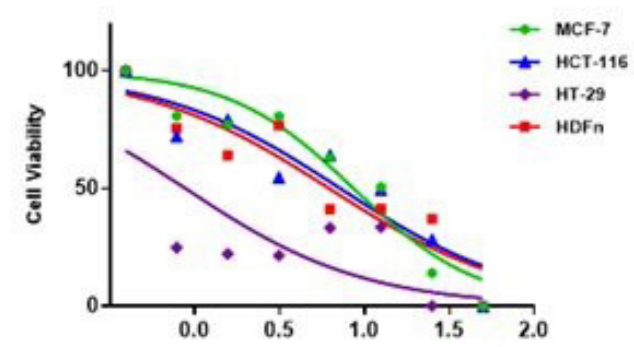

Log of Inhibitor (1) Concentration, $\mu \mathrm{g} / \mathrm{mL}$

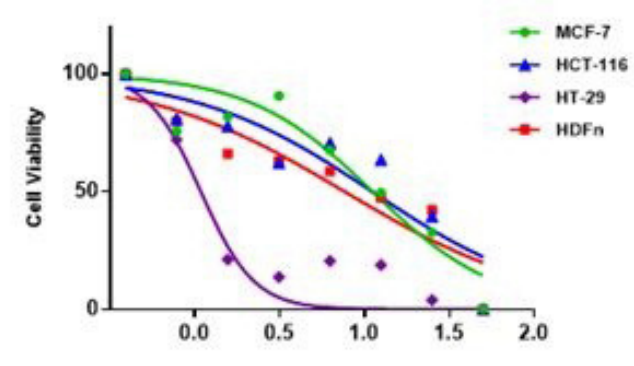

Log of Inhibitor (3) Concentration, $\mu \mathrm{g} / \mathrm{mL}$

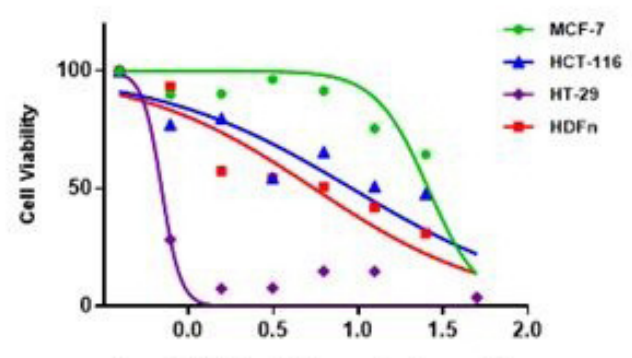

Log of Inhibitor (2) Concentration, $\mu \mathrm{g} / \mathrm{mL}$.

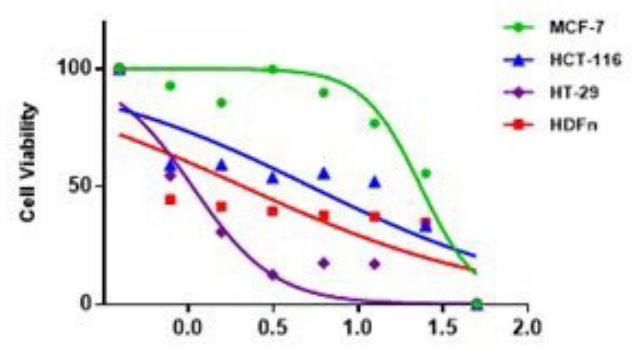

Log of Inhibitor (4) Concentration, $\mu \mathrm{g} / \mathrm{mL}$.

Figure 3: Cytotoxic activities of 1-4 (per compound). Extra sum-of-squares $F$ test was performed to evaluate differences in: $(A)$ best-fit parameters (IC $\left.{ }_{50}\right)$ among treatments, (B) dose-response curve fits. Results: 1 (A) $F(D F n, D F d)=F(3,88)=5.473, p=0.0017$, (B) $F(6,88)=3.085, p=0.0087 ; 2$ (A) $F(3,88)=25.03, p<0.0001$, (B) $F(6,88)=14.24, p<0.0001 ; 3 a$ and $\mathbf{3 b}(A) F(3,88)=8.594, p<0.0001$, (B) $F(6,88)=4.419, p=0.0006 ; 4(A) F(3,88)=15.19, p<0.0001,(B) F(6,88)=7.728, p<0.0001$. 
Table 1: Cytotoxic activities $\left(\mathrm{IC}_{50}\right)$ of 1-4 and Zeocin against MCF-7, HCT-116, HT-29 and HDFn

\begin{tabular}{ccccc}
\hline Sample & \multicolumn{4}{c}{$\mathrm{IC}_{50}{ }^{*}(\mu \mathrm{g} / \mathrm{mL})$} \\
\hline $\mathbf{1}$ & MCF-7 & HCT-116 & HT-29 & HDFn \\
$\mathbf{2}$ & 8.642 & 7.225 & 0.8836 & 6.218 \\
3a and 3b & 25.87 & 9.226 & 0.6931 & 5.519 \\
$\mathbf{4}$ & 11.13 & 11.09 & 1.083 & 7.628 \\
Zeocin & 23.35 & 4.065 & 1.054 & 2.106 \\
\hline
\end{tabular}

${ }^{*}$ IC50 values were extrapolated from dose-response curves generated from nonlinear regression analysis done using GraphPad Prism 7.00. For each cell line, one-way ANOVA was conducted to determine differences between data sets (treatments). The results are: MCF- $7, \mathrm{~F}(5,118)=31.17, \mathrm{p}<0.0001$; HCT-116, $\mathrm{F}(5,117)=84.93, \mathrm{p}<0.0001 ;$ HT-29, $\mathrm{F}(5,118)=65.87, \mathrm{p}<0.0001 ; \mathrm{HDFn}, \mathrm{F}(5$, $118)=51.73, \mathrm{p}<0.0001$. Results of the Tukey's multiple comparison post hoc test are discussed in this section.

the strongest inhibition at the lowest concentrations of the compounds, with $\mathrm{IC}_{50}$ values of $0.6931,0.8836,1.054$, and $1.083 \mu \mathrm{g} / \mathrm{mL}$ for $\mathbf{2}, \mathbf{1}, \mathbf{4}$, and $\mathbf{3} \mathbf{a}$ and $\mathbf{3 b}$, respectively. Tukey's multiple comparison post hoc test showed statistical differences between $\mathbf{2}$ and all other samples except $\mathbf{1}$ $(\mathrm{p}>0.05)$.

The normal cell line, HDFn, responded to all the compounds, with $\mathrm{IC}_{50}$ values of $2.106,5.519,6.218$, and $7.628 \mu \mathrm{g} / \mathrm{mL}$ for $\mathbf{4}, \mathbf{2}, \mathbf{1}$, and $\mathbf{3 a}$ and $\mathbf{3 b}$, respectively. The pairs of compounds, $\mathbf{1}$ and $\mathbf{2}$, and $\mathbf{1}$ and $\mathbf{3 a}$ and $\mathbf{3 b}$ are not statistically different $(\mathrm{p}>0.05)$. All the cell lines are susceptible to Zeocin. Data analysis showed statistical differences in the best-fit parameter (half maximal inhibitory concentration) among treatments and among the dose-response curve fits (Figures 2 and 3).

Overall, comparing the three human cancer cell lines, HT-29 showed the most cytotoxic response with comparable $\mathrm{IC}_{50}$ values for all the compounds tested. This was followed by HCT-116 cells which was most affected by 4 with an $\mathrm{IC}_{50}$ value of 4.065 . Among the cancer cell lines tested, MCF-7 showed the least response to the compounds. The compounds exhibited cytotoxic activities against the normal cell line, HDFn. The known anti-cancer drug, Zeocin, showed anti-proliferative activities as expected. Overall, 1-4 showed varying, but promising cytotoxic properties, especially for the treatment of HT-29 type of colon cancer cells. The US National Cancer Institute has defined the active cytotoxic limits of natural products as $20 \mu \mathrm{g} / \mathrm{mL}$ or less for crude extracts and $4 \mu \mathrm{g} / \mathrm{mL}$ or less for pure compounds. ${ }^{15}$ Pure compounds that exhibit active cytotoxicity may have some potential for drug development. ${ }^{14}$ The results showed that 1-4 from the dichloromethane extracts of K. gitingensis leaves and twigs can be further evaluated for the treatment especially of human colorectal type of cancer.

The study also revealed that the cytotoxic activities of 1-4 were a function of the specific type of cancer cells targeted. When the two colon cancer cell lines were compared, the $\mathrm{IC}_{50}$ values of $\mathbf{1 - 4}$ for HT-29 were lower than HCT-116, implying that the former could be more susceptible to anticancer treatments using the compounds tested. A difference in treatment responses between two colon cancer cell lines was also seen in previous studies. ${ }^{16,17}$ It was reported that changes in the expression profiles of genes associated with drug sensitivity between HCT-116 and HT-29 could influence how the cells react to different inhibitory compounds. ${ }^{18}$ A similar study using four human colon cancer cell lines (HCT-116, HT-29, HCT-15, and KM-12) showed that gene expression profiling after inhibition of signal transduction by 17-allylamino-17-demethoxygeldanamycin, a known inhibitor of the hsp90 molecular chaperone, could explain the cells' response under different treatment parameters. ${ }^{19}$
Previous studies revealed that ursolic acid (1), squalene (2), a-amyrin acetate (3a) lupeol acetate (3b), and isoscopoletin (4) exhibited cytotoxic properties.

Ursolic acid (1) was reported to promote apoptosis in tumor cells by activation of caspases and modulation of pathways influencing cell proliferation and migration..$^{20}$ It also decreased growth and induced apoptosis in gastric cancer cell line BGC-803 and hepatocellular cancer cell $\mathrm{H} 22$ xenograft, both in vivo and in vitro studies. ${ }^{21}$ Other works showed that 1 exhibited anti-tumor activity against human colon carcinoma HCT15 cells, ${ }^{22}$ and inhibited the colon cancer-initiating cells by targeting STAT3. ${ }^{23}$ Triterpene $\mathbf{1}$ and betulinic acid were found useful as therapeutic agents against estrogen-dependent tumors. ${ }^{24}$ Furthermore, the antiproliferative and apoptotic effects of $\mathbf{1}$ was found to have potential therapeutic use against prostate cancer. ${ }^{25} \mathrm{~A}$ recent study reported that 1 suppressed the proliferation of Jurkat leukemic T-cells, inhibiting PMA/PHA induced IL-2 and TNF- $\alpha$ production in a concentration- and time-dependent manner. ${ }^{26}$ Another study using cervical cancer TC-1 cells reported that ursolic acid-activated autophagy induced cytotoxicity and reduced tumor growth in a concentration-dependent manner as well. ${ }^{27}$ The anti-tumor activities of $\mathbf{1}$ against U87MG brain cancer cells were evaluated and it was found that both G1-phase arrest and autophagy were induced by the compound. ${ }^{28}$ In a study evaluating the anti-cancer properties of ursolic acid and three flavonoids, daidzein, baicalein, and hesperidin, it was found that $\mathbf{1}$ and baicalein inhibited the proliferation of MCF-7 breast cancer cells induced by PhIP, a food-derived carcinogen exhibiting estrogenic activities. ${ }^{29}$ The anti-cancer potential of $\mathbf{1}$ present in different berries has been reviewed. ${ }^{20}$ Thus, ursolic acid (1) was reported to exhibit cytotoxic properties against different cancer cells including colon and breast cancer cell lines which corroborate our findings that 1 showed high cytotoxicity against colon cancer cells with the lowest IC $_{50}$ values of $0.8836 \mu \mathrm{g} / \mathrm{mL}$ obtained for HT-29, $7.225 \mu \mathrm{g} / \mathrm{mL}$ for HCT-116, and $8.642 \mu \mathrm{g} / \mathrm{mL}$ for MCF-7.

Squalene (2) was reported to exhibit anti-tumor activities against colon cancer in rodents. ${ }^{30}$ It also reduced colonic aberrant crypt foci (ACF) formation and crypt multiplicity in laboratory rats, indicating potential chemopreventive activities against colon carcinogenesis. ${ }^{31}$ In a study evaluating the anti-proliferative effects of squalene and other compounds from palm oil against two human breast cancer cell lines, MDA-MB-231 and MCF-7, it was found that there was a suppression of nuclear factor kappa-light-chain-enhancer of activated B-cells (NF- $\kappa \mathrm{B}$ ) in breast cancer cells exposed briefly to tumor necrosis factor-alpha (TNF- $\alpha$ ), ${ }^{32,33}$ hence affecting the mechanisms of apoptosis and carcinogenesis. The protective and therapeutic effects of squalene-containing compounds on skin tumor cells in laboratory mice have been reported as well. ${ }^{34}$ Relevant reviews on the bioactive properties of squalene have also been provided. ${ }^{35,36}$ Thus, 2 was reported to exhibit cytotoxic properties against colon and breast cancer cells which corroborate our findings that $\mathbf{2}$ showed high to moderate cytotoxicities against colon cancer cells, HT-29 and HCT-116, and breast cancer cells, MCF-7, with $\mathrm{IC}_{50}$ values of $0.6931,9.226$, and $25.87 \mu \mathrm{g} / \mathrm{mL}$, respectively.

a-Amyrin acetate (3a) was mostly studied for its various potential medicinal applications. At a concentration of $100 \mathrm{mg} / \mathrm{kg}$, 3a isolated from Alstonia boonei showed significant $(\mathrm{p}<0.05)$ inhibition of egg albumen-induced paw edema in mice. ${ }^{37}$ The same study showed that it promoted $60.3 \%$ reduction in total leucocyte count and significant $(\mathrm{p}<0.05)$ suppression $(47.9 \%)$ of neutrophil infiltration. Lupeol, lupeol acetate and $\alpha$-amyrin acetate exhibited significant anti-tyrosinase activity against the mushroom tyrosinase enzyme, with percent inhibitions of $67.7 \%, 66.2 \%$ and $62.2 \%$, respectively, ${ }^{38}$ indicating potential melanin biosynthesis inhibitory properties. Both $\alpha$-amyrin acetate and $\beta$-amyrin acetate were also reported to exhibit sedative, anxiolytic 
and anti-convulsant properties. ${ }^{39}$ Very few studies have been made on the cytotoxic properties of 3a. The dichloromethane extract of Ficus odorata (Blanco) Merr., containing $\alpha$-amyrin acetate, 1 -sitosteryl-3- $\beta$ glucopyranoside-6'-O-palmitate, squalene, lutein, lupeol acetate, and $\beta$-carotene, exhibited anti-proliferative activities against the human cancer cells, lung adenocarcinoma epithelial (A549), stomach adenocarcinoma (AGS), prostate (PC3), and colon adenocarcinoma (HT29). ${ }^{40}$ Lupeol acetate (3b) was reported to exhibit cytotoxic activity against breast cancer cell (MCF7) with an $\mathrm{IC}_{50}$ value of $26 \mu \mathrm{g} / \mathrm{mL}^{41}$ Triterpenes, germincol, lupeol, $\alpha$-amyrin, $\beta$-amyrin, olean-18-ene, and lupeol acetate, were isolated from the methanol extract of leaves and stems of Lactuca steriolla and showed varying cytotoxic activities against non-small cell lung adenocarcinoma cells (A549), human hepatocellular liver carcinoma cells (HepG2), human breast carcinoma cells (MCF7) and human colon carcinoma cells (HCT116). ${ }^{42}$

The chloroform extract of the leaves of Acokanthera oblongifolia, containing mixtures of isolated triterpenes, $\alpha$-amyrin, lupeol acetate, lupeol, betulinaldehyde, and betulinic acid, showed some cytotoxic activities against human cancer cell lines, hepatocellular carcinoma (HepG2), breast adenocarcinoma (MCF7) and colorectal (HCT116), with $\mathrm{IC}_{50}$ values of $37.6,65.4$ and $66.8 \mu \mathrm{g} / \mathrm{ml}$, respectively. ${ }^{43}$ Thus, $3 \mathbf{a}$ and $\mathbf{3 b}$ were reported to exhibit cytotoxic properties against colon and breast cancer cells which corroborate our findings that the mixture of $\mathbf{3 a}$ and $\mathbf{3 b}$ showed high to moderate cytotoxic properties against colon cancer cells, HT-29 and HCT-116, and breast cancer cells, MCF-7, with IC $_{50}$ values of $1.083,11.09$, and $11.13 \mu \mathrm{g} / \mathrm{mL}$, respectively. It is hypothesized that the synergistic effects of both compounds could have caused the observed anti-proliferative effects against the cancer cells studied.

Isoscopoletin (4) showed substantial inhibition in a cell proliferation assay using human CCRF-CEM leukaemia cells with an $\mathrm{IC}_{50}$ value of $4.0 \mu \mathrm{M} .{ }^{44}$ Another study reported that $\mathbf{4}$ exhibited cytotoxic activities against human lung cancer (A549), human breast cancer cell (MCF7) and human liver cancer (HepG2) with $\mathrm{IC}_{50}$ values of $5.25,8.58$ and $4.76 \mu \mathrm{M}$, respectively. ${ }^{45}$ Moreover, 4 showed cytotoxicity against colon cancer (HCT116) cells with an $\mathrm{IC}_{50}$ value of $10 \%$ at 100 ppm. ${ }^{46}$ Compound 4 from Artemisia argyi, artemisinin from Artemisia annua, and the latter's semi-synthethic derivative, artesunate, showed the greatest activity in in vitro cytotoxicity tests against HCT116 colon adenocarcinoma cell line, with $\mathrm{IC}_{50}$ values ranging in concentration from micromolar to millimolar amounts. ${ }^{47}$ It was hypothesized that isoscopoletin enhanced its anti-cancer property by influencing the activity of p53 tumor protein which is a genetically important process in cancer progression. Thus, 4 was reported to exhibit cytotoxic properties against several cancer cell lines such as colon and breast which corroborate our findings that 4 showed varying cytotoxic activities against colon cancer cells, HT-29 and HCT-116, and breast cancer cells, MCF-7, with $\mathrm{IC}_{50}$ values of 1.054, 4.065 , and $23.35 \mu \mathrm{g} / \mathrm{mL}$, respectively. Compound 4 also exhibited the highest cytotoxicity against the human dermal fibroblast-neonatal (HDFn) normal cell line, with an $\mathrm{IC}_{50}$ value of $2.106 \mu \mathrm{g} / \mathrm{mL}$. More studies are needed to fully examine and understand the effects of 4 on normal cells.

\section{CONCLUSION}

Ursolic acid (1), squalene (2), a mixture of $\alpha$-amyrin acetate (3a) and lupeol acetate (3b), and isoscopoletin (4) from the dichloromethane extracts of Kibatalia gitingensis exhibited varying cytotoxic activities against three human cancer cell lines, breast (MCF-7) and colon (HT-29 and HCT-116), and a normal cell line, human dermal fibroblast - neonatal (HDFn). The anti-proliferative activities of 1-4 were highest against HT-29, with $\mathrm{IC}_{50}$ values ranging from 0.6931 to $1.083 \mu \mathrm{g} / \mathrm{mL}$, followed by $\mathrm{HCT}-116$, with $\mathrm{IC}_{50}$ values ranging from 4.065 to $11.09 \mu \mathrm{g} / \mathrm{mL}$, and
MCF-7, with $\mathrm{IC}_{50}$ values ranging from 8.642 to $25.87 \mu \mathrm{g} / \mathrm{mL}$. Compounds 1-4 were also cytotoxic against $\mathrm{HDFn}$ with $\mathrm{IC}_{50}$ values ranging from 2.106 to $7.628 \mu \mathrm{g} / \mathrm{mL}$.

\section{ACKNOWLEDGEMENT}

A research grant from the De La Salle University Science Foundation, through the University Research Coordination Office, De La Salle University, Manila, Philippines, is gratefully acknowledged. Plant samples were authenticated by Dr. Emelina H. Mandia of the Biology Department, De La Salle University.

\section{CONFLICT OF INTEREST}

There is no conflict of interest.

\section{REFERENCES}

1. World Conservation Monitoring Centre. 1998. Kibatalia gitingensis. The IUCN Red List of Threatened Species 1998: e.T37341A10045636. http://dx.doi. org/10.2305/IUCN.UK.1998.RLTS.T37341A10045636.en.

2. Dayan Md P, Reaviles RS, Bandian Indigenous DB. Forest Tree Species in Laguna Province. DENR Recommends. 2006;5a:7-8.

3. Aguilar-Santos G. Gitingensine, a new alkaloid from the leaves of Kibatalia gitingensis. Philipp J Sci. 1965;94:217-20.

4. Aguilar-Santos G, Santos E, Crabbé P. Stereo chemistry of the alkaloid gitingensine. J Org Chem. 1967;32(8):2642-4. http://dx.doi.org/10.1021/jo01283a069; PMid:6043949

5. Estrada HR, Aguilar-Santos G. Pharmacologic and chemical studies on gitingensine, a new azasteroidal alkaloid. J Philipp Med Assoc. 1966;42(11):703-24. PMid:5978410.

6. Janot MM. Paravallaris microphylla and Kibatalia gitingensis alkaloids. Colloques Internation aux du Centre National de la Recherche Scientifique. 1966;144:12745.

7. Cave A, Potier P, Le Men J. Steroidal alkaloids of Apocynaceae. VI. Structure of kibataline. Alkaloid from Kibatalia gitingensis. Bulletin de la Societe Chimique de France. 1964;10:2415-8.

8. Cave A, Potier P, Le Men J. Steroid alkaloids of Apocynaceae. IX. Isolation of 20-(epi-N-methyl) paravallarine from the leaves of Kibatalia gitingensis. Bulletin de la Societe Chimique de France.1965;9:2502-5.

9. Estrada HR, De Leon GV, Lim PR, Valdez EV. Effects of an a zasteroidal alkaloid from Kibatalia gitingensis (Woods) on bronchomotos tone. Act a Medica Philippina. 1964;1:1-4. PMid:14231881.

10. Cave A, Potier P, Le Men J. Alkaloids of the bark of Kibatalia gitingensis (Elm.) Woods (Apocynaceae). Steroid alkaloids of Aocynaceae. 14th report. Annales Pharmaceutiques Francaises. 1967;25(2):107-14. PMid:5600766.

11. Rahmann AU, Muzaffar A. Steroidal Alkaloids of A pocynaceae and Buxaceae. The Alkaloids: Chemistry and Pharmacology. 1988;32:179-239.

12. Ragasa CY, VAS Ng, De Los Reyes MM, Mandia EH, Shen C-C. Triterpenes and a coumarin derivative from Kibatalia gitingensis (EIm.) Woodson. Der Pharma Chemica. 2014;6(5):360-4

13. Freshney RI. Culture of Animal Cells: A Manual of Basic Techniques. New York, U.S.A.: Wiley-Liss, Inc. 2000. PMCid:PMC2374402.

14. Jacinto SD, Chun EAC, Montuno AS, Shen C-C, Espineli DL, Ragasa CY. Cytotoxic cardenolide and sterols from Calotropis gigantea. Nat Prod Commun. 2011;6(6):803-6. PMid:21815415.

15. Geran RI, Greenberg NH, McDonald MM, Schumacher AM, Abbott BJ. Protocols for screening chemical agents and natural products against animal tumour and other biological systems. Cancer Chemother Rep. 1972;3:17-9.

16. De Los Reyes MM, Oyong GG, Ebajo Jr. VD, Ng VAS, Shen C-C, Ragasa CY. Cytotoxic triterpenes and sterols from Pipturus arborescens (Link) C.B. Rob. J Applied Pharma Sci. 2015;5(11):23-30. http://dx.doi.org/10.7324/JAPS.2015. 501104

17. De Los Reyes MM, Oyong GG, Ng VAS, Shen C-C and Ragasa CY. Cytotoxic compounds from Dysoxylum gaudichaudianum (A. Juss.) Miq. Int J Pharmacog Phytochemical Res. 2016;8(4):668-74.

18. Makizumi R, Yang W-L, Owen RP, Sharma RR, Ravikumar TS. Alteration of drug sensitivity in human colon cancer cells after exposure to heat: implications for liver metastasis therapy using RFA and chemotherapy. Int J Clin Exp Med. 2008;1(2):117-29. PMid:19079666 PMCid:PMC2596320.

19. Clarke PA, Hostein I, Banerji U, Di Stefano F, Maloney A, Walton M, et al., Gene expression profiling of human colon cancer cells following inhibition of signal transduction by 17-allylamino-17-demethoxygeldanamycin, an inhibito of the hsp90 molecular chaperone. Oncog. 2000;19(36):4125-33. http://dx.doi. org/10.1038/sj.onc.1203753; PMid:10962573.

20. Neto CC. Ursolic acid and other pentacyclic triterpenoids anticancer activities 
and occurrence in berries. In: Stoner GD, Seeram NP, editors. Berries and Cancer Prevention. Springer Science+Business Media, LLC ;2011:pp.41-9. http:// dx.doi.org/10.1007/978-1-4419-7554-6_2; PMid:21251133.

21. Wang $X$, Zhang F, Yang L, MeiY, Long $H$, Zhang X. Ursolic acid inhibits proliferation and induces apoptosis of cancer cells in vitro and in vivo. J Biomed Biotechnol. 2011;Article ID 419343. http://dx.doi.org/10.1155/2011/419343.

22. Li J, Guo W-J, Yang Q-Y. Effects of ursolic acid and oleanolic acid on human colon carcinoma cell line HCT15. World J Gastroenterol. 2002;8(3):493-5. http:// dx.doi.org/10.3748/wjg.v8.i3.493; PMid:12046077 PMCid:PMC4656428.

23. Wang W, Zhao C, Jou D, Lu J, Zhang C, Lin L, et al. Ursolic acid inhibits the growth of colon cancer-initiating cells by targeting STAT3. Anticancer Res. 2013;33(10):4279-84. PMid:24122993.

24. Kim H-I, Quan F-S, Kim J-E, Lee N-R, Kim HJ, Jo SJ. Inhibition of estrogen signaling through depletion of estrogen receptor alpha by ursolic acid and betulinic acid from Prunella vulgaris var. lilacina. Bio chem Biophys Res Commun. 2014;451(2):282-7. http://dx.doi.org/10.1016/j.bbrc.2014.10.052; http://dx.doi. org/10.1016/j.bbrc.2014.07.115; PMid:25088993.

25. Kassi E, Papoutsi Z, Pratsinis H, Aligiannis N, Manoussakis, Moutsatsou P. Ursolic acid, a naturally occurring triterpenoid, demonstrates anticancer activity on human prostate cancer cells. J Cancer Res Clin Oncol. 2007;133(7):493-500. http://dx.doi.org/10.1007/s00432-007-0193-1; PMid:17516089.

26. Kaewthawee N, Brimson S. The effects of ursolic acid on cytokine production via the MPKA pathways in leukemic T-cells. EXCLIJ. 2013;12:102-14.

27. Leng S, HaoY, Du D, Xie S, Hong L, Gu H, et al. Ursolic acid promotes cancer cell death by inducing Atg5-dependent autophagy. Int J Cancer. 2013;133(12):2781-90. http://dx.doi.org/10.1002/ijc.28301.

28. Shen $S$, Zhang $Y$, Zhang $R$, Tu X, Gong $X$. Ursolic acid induces autophagy in U87MG cells via ROS-dependent endoplasmic reticulum stress. ChemicoBiol Interact. 2014;218:28-41. http://dx.doi.org/10.1016/j.cbi.2014.04.017; PMid:24802810.

29. Lee MN, Lee SY, Lee HJ, Seok JH, Lee CJ. Anti-proliferative effects of daidzein, baicalein, hesperidin and ursolic acid on human breast cancer cells stimulated by estrogenic compounds. Yakhak Hoechi. 2010;54(3):168-73.

30. Spanova M, Daum G. Review Article: Squalene-biochemistry, molecular biology, process biotechnology, and applications. Eur J Lipid Sci Technol. 2011;113(11):1299-320. http://dx.doi.org/10.1002/ejlt.201100203.

31. Rao CV, Mark HLN, Reddy RS. Chemo preventive effect of squalene on colon cancer. Carcinogenesis. 1998;19(2):287-90. http://dx.doi.org/10.1093/carcin/19.2.287; PMid:9498278.

32. Loganathan R, Radhakrisnan AK, Selvaduray KR, Nesaretnam K. Selective anticancer effects of palm phyto nutrients on human breast cancer cells. Royal Soc Chem Adv. 2015;5(3):1745-53.

33. Loganathan R, Selvaduray KR, Nesaretnam K, Radhakrisnan A. Differential and antagonistic effects of palm tocotrienols and other phytonutrients (carotenoids, squalene and coenzyme 010) on breast cancer cells in vitro. J Oil Palm Res. 2013;25(2):208-15
34. Desai KN, Wei H, Lamartiniere CA. The preventive and therapeutic potential of the squalene-containing compound, Roidex, on tumor promotion and regression. Cancer Letters. 1996;101(1):93-6. http://dx.doi.org/10.1016/03043835(96)04122-5.

35. Ronco AL, De Stéfani E. Squalene: a multi-task link in the crossroads of cancer and aging. Functional Foods in Health and Disease. 2013;3(12):462-76.

36. Chudzik M, Korzonek-Szlacheta I, Król W. Triterpenes as potentially cytotoxic compounds. Molec. 2015;20(1):1610-25. http://dx.doi.org/10.3390/molecules 20011610; PMid:25608043.

37. Okoye NN, Ajaghaku DL, Okeke HN, Ilodigwe EE, Nworu CS, Okoye FBC. BetaAmyrin and alpha-amyrin acetate isolated from the stem bark of Alstoniaboone display profound anti-inflammatory activity. Pharm Biol. 2014;52(11):1478-86. http://dx.doi.org/10.3109/13880209.2014.898078; PMid:25026352.

38. Muhammad A, Ya'u M, Sirat HM. I J Chem Molec Eng Abstract 1053. http:// iastem.com/Abstracts/chemical-and-molecular-engineering? \&page $=7$.

39. Aragão GF, Carneiro LMV, Junior APF, Bandeira PN, Lemos ILG, Viana GSdB. Evidence for excitatory and inhibitory amino acids participation in the neuropharmacological activity of alpha- and beta-amyrin acetate. The Open Pharmacol J. 2009;3:9-16. http://dx.doi.org/10.2174/1874143600903010009.

40. Tsai P, Castro-Cruz K, Shen, Chiou C, Ragasa C. Chemical constituents of Ficusodorata. Pharm Chem J. 2012;46(4):225-7. http://dx.doi.org/10.1007/ s11094-012-0767-3.

41. Lee YS, Tee CT, Tan SP, Khalijah A, Najihah $\mathrm{MH}$, et al., Cytotoxic, antibacterial and antioxidant activity of triterpenoids from Kopsia singapuresis Ridl. J Chem Pharm Res. 2014;6(5):815-22

42. Elsharkawy E, Alshathly M. Anticancer activity of Lactuca steriolla growing under dry desert condition of Northern Region in Saudi Arabia. J Nat Sci Res. 2013;3(2):5-19.

43. Hassan RA, Hassan EM, Ibrahim NA, Nazif NM. Triterpenes and cytotoxic activity of Acokanthera oblongifolia Hochst. Res J Pharm Biol Chem Sci. 2015;6(1):1677-86.

44. Adams M, Efferth T, Bauer R. Activity-guided isolation of scopoletin and isoscopoletin. Planta Med. 2006;72(9):862-4. http://dx.doi.org/10.1055/s-2006-947165; PMid:16881019.

45. Zhao D-D, Zhao Q-S, Liu L, Chen Z-Q, Zeng W-M, Lei H, et al. Compounds from Dryopteris fragrans (L.) Schott with cytotoxic activity. Molecules. 2014;19(3):3345-55. ․ http://dx.doi.org/10.3390/molecules19033345; PMid:24647035.

46. Mohammed MMD, Spiteller M, Ibrahim NA, Mohamed KM. Cytotoxic activity of new tropineneglycoside isolated from Solandra grandiflora Sw. Rec Nat Prod. 2016;10(3):385-91.

47. Mc Govern PE, Christofidou-Solomidou M, Wang W, Dukes F, Davidson T, El-Deiry WS. Anticancer activity of botanical compounds in ancient fermented beverages (Review). Int J Oncol. 2010;37:5-14. http://dx.doi.org/10.3892/ ijo_00000647; PMid:20514391

Cite this article: De Los Reyes M M, Oyong G G, Antonio S. Ng V, Shen C C, Ragasa C Y. Cytotoxic Compounds from Kibatalia gitingensis (Elm.) Woodson Pharmacognosy Journal. 2017;9(1):1-7. 